\title{
Oxidation Behavior of Continuous SiC Fibers in Static Air
}

\author{
Liang $\mathrm{Li}^{\mathrm{a}}$, Ke Jian ${ }^{\mathrm{b},{ }^{*}}$, Yifei Wang ${ }^{\mathrm{c}}$ \\ Science and Technology on Advanced Ceramic Fibers and Composites Laboratory, \\ National University of Defense Technology, Changsha 410073, PR China \\ 546780152@qq.com, jianke_nudt@163.com, wangyf314@163.com
}

Keywords: SiC; fiber; Nicalon; Hi-Nicalon; oxidation.

Abstract. This paper studied the oxidation behavior of the Nicalon and Hi-Nicalon type of continuous $\mathrm{SiC}$ fibers. The fibers were exposed in air at $1000-1400^{\circ} \mathrm{C}$ for $1 \mathrm{~h}$. Experimental results indicate that both Nicalon and Hi-Nicalon SiC fibers' tensile strength decrease, whereas oxygen content increase with rising oxidizing temperature. The XRD results showed that the crystallinity of Hi-Nicalon is better than Nicalon fibers. The amorphous oxide film began to crystallize into $\alpha$-cristobalite at $1400^{\circ} \mathrm{C}$. By comparing the same conditional experiments for Nicalon and Hi-Nicalon SiC fibers, the differences between Nicalon and Hi-Nicalon SiC fibers about the antioxidant properties and the effect of heat treatment on the structure and properties of $\mathrm{SiC}$ fibers have been discussed.

\section{Introduction}

Continuous SiC fibers reinforced ceramic matrix composites (SiC-CMC), has high strength, high modulus and excellent high temperature performance, which has been widely used in aerospace, advanced weaponry, nuclear energy and many other fields [1-3].Compared to the traditional high temperature alloys, when SiC-CMC used in aviation engines, the operating temperature of aviation engine could be increased by more than $200^{\circ} \mathrm{C}$, the weight of the structure decreased more than $30 \%$ and fuel efficiency increased by $10 \%$. It can be seen that SiC-CMC has become the important and indispensable materials for the aviation aircraft [4-6]. However, due to the SiC-CMC used in the oxidizing environment with above $1000^{\circ} \mathrm{C}$, especially for the engine combustion exposed in the high temperature steam environment, as the reinforcement of $\mathrm{SiC}-\mathrm{CMC}$, the oxidation of $\mathrm{SiC}$ is a concern [7]. T.Takeda's work has showed that the strength retention rate of Hi-Nicalon was around 50\% after oxidation in air at $1200^{\circ} \mathrm{C}$ for $1 \mathrm{~h}$ [8]. With the decline in the strength of the $\mathrm{SiC}$ fibers after oxidation and its broad application prospects, it is needed to study the oxidation behavior of $\mathrm{SiC}$ fibers.

Previous works on oxidation behavior of $\mathrm{SiC}$ have been reported. Yuan T.Zhu has studied the thermodynamic process of the passive oxidation about the Nicalon [9]. T. Shimoo and F.Toyoda have studied the thermal stability of $\mathrm{SiC}$ fibers after preoxidation under different oxygen partial pressure [10]. S.J.Wu has analyzed the oxidation behavior of Nicalon in wet air [11]. Z.D.Feng has studied the changes of structure and properties of Hi-Nicalon after oxidation under simulated aero-engine combustor environment [12]. There are many reports for the oxidation of Nicalon and Hi-Nicalon, but few studies has been reported about the difference oxidation behavior of Nicalon series (Nicalon and Hi-Nicalon) of SiC fibers at different temperature. Therefore, in this work, the fibers' tensile strength, oxygen content, microstructure and morphology have been tested and measured before and after oxidation, respectively. The oxidation behavior of Niclaon series $\mathrm{SiC}$ fibers was analyzed and the differences between Nicalon and Hi-Nicalon SiC fibers in the antioxidant properties have been discussed.

\section{Experimental Procedure}

The Nicalon series (Nicalon and Hi-Nicalon, manufactured by Carbon Company, Japan) SiC fibers, were put in the muffle furnace and then heated to $1000^{\circ} \mathrm{C}, 1100^{\circ} \mathrm{C}, 1300^{\circ} \mathrm{C}$ and $1400^{\circ} \mathrm{C}$ for $1 \mathrm{~h}$, respectively, with the heating rate of $10^{\circ} \mathrm{C} / \mathrm{min}$. The strength of fibers was determined by a monofilament tensile testing machine (Micro 350, Testometric, UK), with 25mm for the test length and 
$5 \mathrm{~mm} / \mathrm{min}$ for the tensile speed, and each result is the average of 20 times tests. And their oxygen content were measured by EMGA-820(Horiba, Japan), microstructure by X-ray-diffractometer (D8 Advance, Bruker AXS, German), and morphology by FESEM (Quanta FEG 250, FEI, American).

\section{Results and discussion}

\section{Mechanical Properties}

Fig. 1 shows residual tensile strength and Young's modulus of the Nicalon and Hi-Nicalon two kinds of $\mathrm{SiC}$ fibers oxidized in air, at $1000^{\circ} \mathrm{C}, 1100^{\circ} \mathrm{C}, 1300^{\circ} \mathrm{C}$ and $1400^{\circ} \mathrm{C}$ for $1 \mathrm{~h}$, respectively. It is obvious that oxidation has caused severe strength degradation and the impact on the Young's modulus is relatively small. Compared with the second generation of low oxygen content Hi-Nicalon SiC fibers, the strength and Young's modulus of the first generation of high oxygen content Nicalon SiC fibers are relatively low. During $1000-1100^{\circ} \mathrm{C}$, Nicalon SiC fibers appear serious decline in strength, which was caused by the Si-C-O phase thermal decomposition. This decomposition would lead to the emergence of pores, cracks and other defects, and finally lead to a serious deterioration in fibers strength [13-14]. After oxidation at $1200^{\circ} \mathrm{C}$ and $1400^{\circ} \mathrm{C}$ for $1 \mathrm{~h}$, the strength of Hi-Nicalon $\mathrm{SiC}$ fibers can be maintained around 1.3GPa and $1 \mathrm{Gpa}$, respectively. Compared with Nicalon, it can be seen that by reducing the $\mathrm{Si}-\mathrm{C}-\mathrm{O}$ phase which is unstable at high temperature, strength of Hi-Nicalon $\mathrm{SiC}$ fibers has been improved as-received or after oxidation. It can be concluded that the antioxidant properties of SiC fibers can be enhanced by reducing the oxygen content.
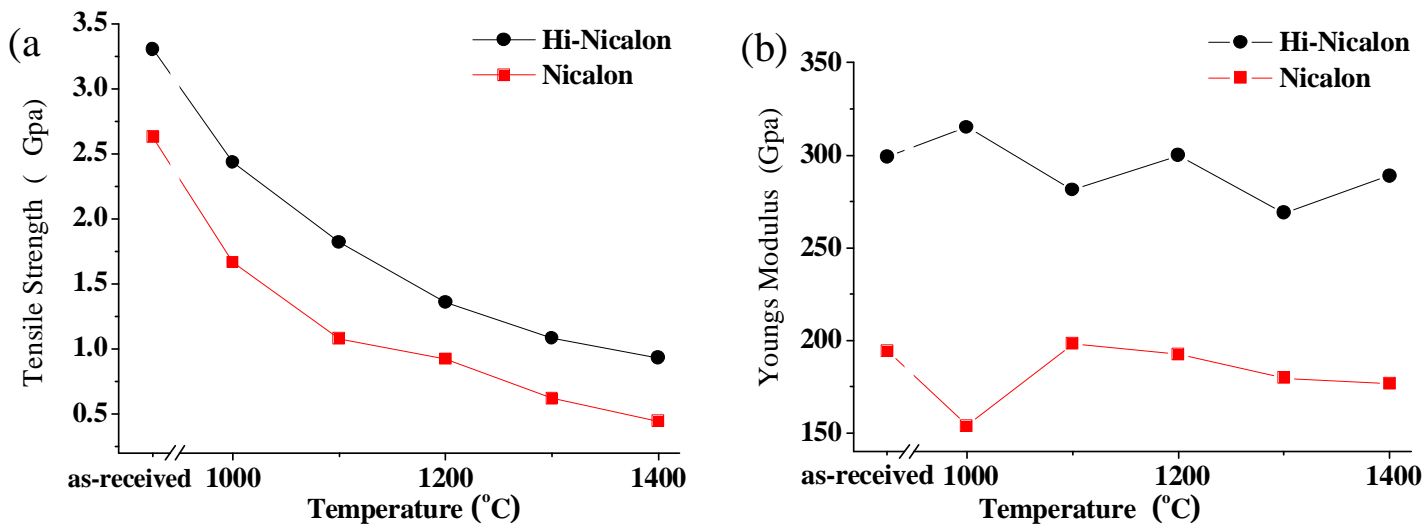

Fig. 1 Tensile strength and Young's modulus of SiC fibers after oxidation in air for $1 \mathrm{~h}$ (a) Tensile strength, (b) Young's modulus

\section{Compositional Analysis}

The oxygen content of the oxidized samples are indicated in Table 1.For Nicalon $\mathrm{SiC}$ fibers, due to the $\mathrm{Si}-\mathrm{C}-\mathrm{O}$ phase thermal decomposition, the oxygen content has a slight decline during $1000-1100^{\circ} \mathrm{C}$ [15], and when oxidation above $1200^{\circ} \mathrm{C}$, the oxygen content has increased. For the Hi-Nicalon $\mathrm{SiC}$ fibers, which are low oxygen content $\mathrm{SiC}$ fibers, it clearly appears that the oxygen content increases by rising the oxidation temperature. Generally, in terms of the trend of oxygen content changes after oxidation, the Nicalon and Hi-Nicalon SiC fibers have similar trend about the oxygen content after oxidation in air with rising temperature. 
Tab.1 Oxygen content of SiC fibers after oxidation in air for $1 \mathrm{~h}$

\begin{tabular}{|c|c|c|c|}
\hline \multirow[b]{2}{*}{ Treatment } & Sample & Nicalon & Hi-Nicalon \\
\hline & & \multicolumn{2}{|c|}{ Oxygen content (wt\%) } \\
\hline as-received & & 8.6 & 0.8 \\
\hline $1000^{\circ} \mathrm{C}-1 \mathrm{~h}$ & & 11.0 & 1.7 \\
\hline $1100^{\circ} \mathrm{C}-1 \mathrm{~h}$ & & 10.7 & 2.4 \\
\hline $1200^{\circ} \mathrm{C}-1 \mathrm{~h}$ & & 11.1 & 2.5 \\
\hline $1300^{\circ} \mathrm{C}-1 \mathrm{~h}$ & & 11.7 & 3.3 \\
\hline $1400^{\circ} \mathrm{C}-1 \mathrm{~h}$ & & 11.8 & 4.0 \\
\hline
\end{tabular}

\section{X-ray diffraction profile}

Fig.2(a) has showed the XRD patterns of Nicalon SiC fibers as-received and after oxidation in air at different temperature, respectively. It can be seen that the crystallinity of Nicalon SiC fibers is not so well and is close to amorphous at a certain degree. It can been seen that the XRD patterns of Nicalon $\mathrm{SiC}$ fibers has the peak of free carbon when oxidation below $1200^{\circ} \mathrm{C}$ and the peak of free carbon has disappeared above $1300^{\circ} \mathrm{C}$. When the oxidation temperature exceeds $1400^{\circ} \mathrm{C}, \alpha$-cristobalite diffraction peaks began to appear. Fig.2(b) has showed the XRD patterns of Hi-Nicalon. It is clearly that the crystallinity of Hi-Nicalon is well. The XRD patterns exhibit three main peaks of $\beta$-SiC, which are assigned to the (111)plane with $2 \theta=35.597^{\circ}$, (220)plane with $2 \theta=59.977^{\circ}$ and (311)plane with $2 \theta=71.777^{\circ}$, respectively [16]. The three main broad scattering humps almost unchanged with rising oxidation temperature, except that the peak of $\alpha$-cristobalite began to appear when oxidizing exceed $1400^{\circ} \mathrm{C}$. Compared to the XRD patterns of Nicalon and Hi-Nicalon, both Nicalon and Hi-Nicalon exist the free $\mathrm{C}$ peak when oxidizing temperature below $1200^{\circ} \mathrm{C}$. The average crystallite sizes of $\beta$-SiC grains of Hi-Nicalon has increased a little, which have been calculated from the half-value width of the (111) peak by using the Scherrer equation [17].
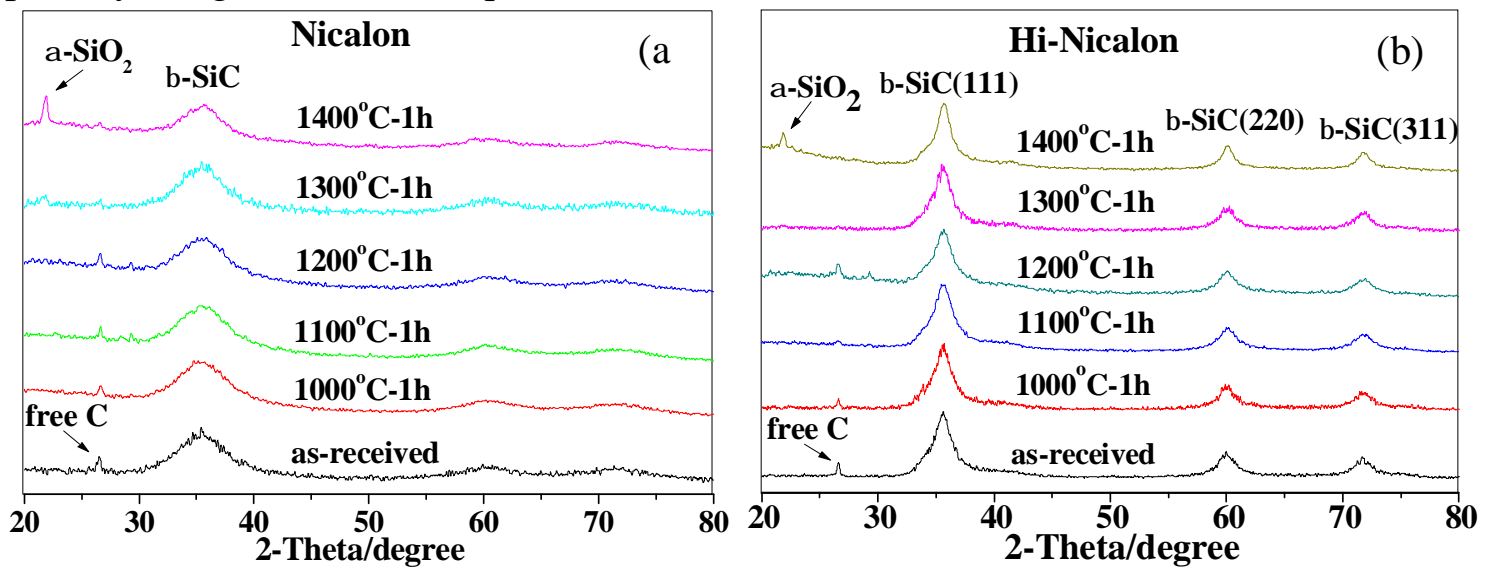

Fig. 2 XRD patterns of (a) Nicalon, (b) Hi-Nicalon

\section{Morphology analysis}

In order to investigate the oxidation behavior and strength degradation of Niclaon series fibers, the structural changes of the fibers were examined by SEM analysis. Fig.3(a) shows the surface and cross section morphologies of Hi-Nicalon $\mathrm{SiC}$ fibers as-received. It can be clearly observed that the fiber surface is smooth, and the edge of the cross section is relatively flat. And the morphology is similar to the previous reports about the morphology of Hi-Nicalon without heat treatment [18]. Fig.3(b) shows the surface and cross section morphologies of Hi-Nicalon $\mathrm{SiC}$ fibers after oxidation $1200^{\circ} \mathrm{C}$ in air for $1 \mathrm{~h}$, it can be seen that the fiber surface becomes relatively rough, with flaky oxide, and the cross-sectional becomes unevenness. It can be clearly observed from the cross section that the oxide layer has formed. In previous works about the oxidation of $\mathrm{SiC}$ fibers, they have described the 
oxidation behavior of Nicalon and Hi-Nicalon. Due to decomposition of the Si-C-O phase in the Nicalon fibers and the product gas overflow through the fiber, the surface of Nicalon fibers become very rough and appears much cracks, with the results of tensile strength decreasing. With a low oxygen content, Hi-Nicalon has a higher strength retention than Nicalon after oxidation [19-21].
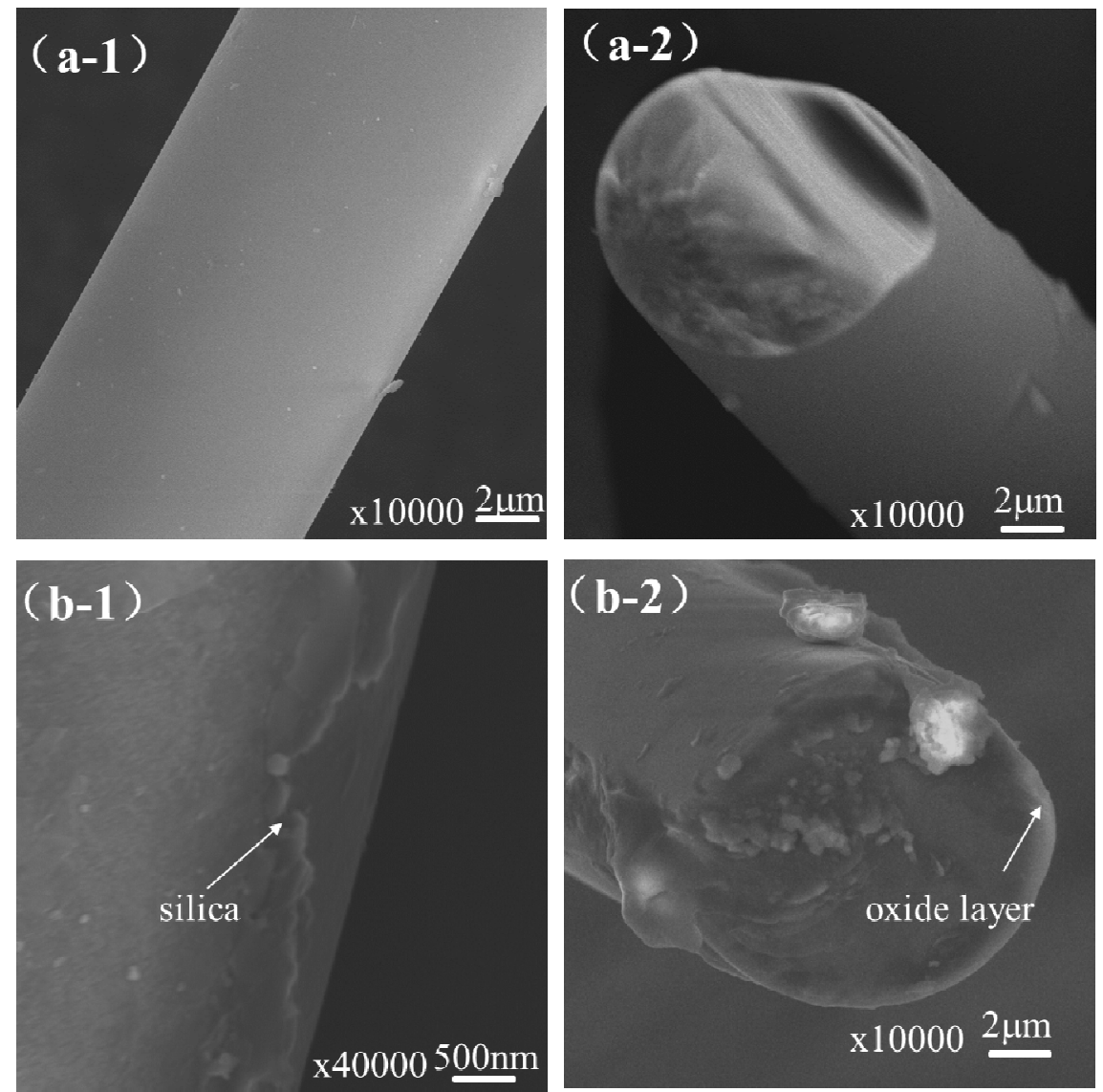

Fig.3 The morphology of Hi-Nicalon SiC fibers (a) as-received, (b) $1200^{\circ} \mathrm{C}-1 \mathrm{~h}$

\section{Conclusions}

(1) Compared with Nicaon SiC fibers, Hi-Nicalon has much higher strength and Young's modulus, and both Nicalon and Hi-Nicalon SiC fibers strength have decreased with the increase of oxidation temperature.

(2) Due to the Si-C-O phase thermal decomposition, the oxygen content of Nicalon SiC fibers has a slight decline during $1000 \sim 1100^{\circ} \mathrm{C}$, and the oxygen content of Hi-Nicalon SiC fibers has increased with the rising oxidation temperature.

(3) The crystallinity of Hi-Nicalon SiC fibers is better than Nicalon fibers. When the oxidizing temperature exceeds $1400^{\circ} \mathrm{C}$, the amorphous oxide film begins to crystalline into $\alpha$-cristobalite.

(4) The surface morphologies of Hi-Nicalon SiC fiber have become rough after oxidized.

By comparing Nicalon with Hi-Nicalon, which has low oxygen content, it can be concluded that the mechanical property of oxidation resistance of $\mathrm{SiC}$ fibers has been improved by reducing the Si-C-O unstable phase.

\section{References}

[1]H.Ohnabe, S.Masaki,M.Onozuka, et al. Potential application of ceramic matrix composites to aero-engine components. Part A: Appl.Sci.Manuf. 30(1999)489-496.

[2]Naslain R. CVI composites. In: Warren R, editor. Ceramic matrix composites. London: Chapman \& Hall;1992.p. 192. 
[3] K.Yoshida. Development of silicon carbide fiber-reinforced silicon carbide matrix composites with high performance based on interfacial and microstructure control. J Ceram. Sco. Jpn. 118 (2010)82-90.

[4]S.W.Li,Z.D.Feng,Y.S.Liu,et al. Microstructural evolution of coating-modified 3D C/SiC composites after annealing in wet oxygen at different temperatures. Corros. Sci.52(2011) 2837-2845. [5]S.Yajima, K.Okamura, J.Hayashi. Structural analysis in continuous silicon carbide of high strength. Chem.Lett.12(1975)1209-1212.

[6]C.M.Zheng,X.D.Li,H.Wang,et al. Thermal stability and curing kinetics of polycarbosiliane fibers. Trans.Nonferrous Met.Soc.China.16(2006)44-48.

[7]N.S.Jacobson. Corrosion of silicon-based ceremics in combustion environments. J.Am.Ceram.Soc.76(1993)3-28.

[8]M.Takeda,A.Urano,J.Sakamoto,et al. Microstructure and oxidation degradation behavior of silicon carbide fiber Hi-Nicalon type S. J.Nucl.Mater.258-363(1998)1594-1599.

[9]Yuntian T.Zhu,Seth T.Taylor,Michael G.Stout,et al. Kinetics of Thermal, Passive Oxidation of Nicalon Fibers.J.Am.Ceram.Soc.81(1998)655-660.

[10]T.Shimoo,F.Toyada,K.Okamura. Thermal Stability of Low-Oxygen Silicon Carbide Fiber (Hi-Nicalon) Subjected to Selected Oxidation Treatment. J.Am.Ceram.Soc.81(2000)1450-1456.

[11]S.J.Wu, L.F.Cheng, L.T.Zhang, Y.D.Xu ,et al.Wet oxidation behaviors of Hi-Nicalon fibers.Appl.Surf.Sci.253(2006)1447-1450.

[12]R.Q.Yao,Z.D.Feng,L.F.Chen,et al.Oxidation behavior of Hi-Nicalon $\mathrm{SiC}$ monofilament fibers in air and $\mathrm{O}_{2}-\mathrm{H}_{2} \mathrm{O}-\mathrm{Ar}$ atmospheres. Corros. Sci.57(2012) 181-191.

[13]R.Bodet,N.Jia,R.E.Tressler. Microstructural Instability and Resultant Strength of Si-C-O (Nicalon) and Si-N-C-O(HPZ)fibers.J.Euro.Ceram.Soc.16(1996)653-664.

[14]T.M.Zima, N.I.Baklanova, A.T.Titov. The behavior of oxided-coated Nicalon $^{\mathrm{TM}}$ fibers exposed to air at $1000^{\circ}$ C. J.Euro.Ceram.Soc. 25(2005)1943-1952.

[15]N.Miriyala,P.K.Liaw,C.J.McHargue,et al. The mechanical behavior of a Nicalon/ SiC composite at room temperature and $1000^{\circ}$ C. J.Nucl.Mater.253(1998)1-9.

[16]J.J.Sha,J.S.Park,T.Hinoki,et al. Heat treatment effects on creep behavior of polycrystalline SiC fibers.Mater.Chara.57(2006)6-11.

[17]A.R.Bunsell,G.Simon.Mechanical and structural characterization of Nicalon SiC fibers up to 1300C.Compos.Sci.Technol.27(1986)157-171.

[18]J.J.Sha,T.Hinoki,A.Kohyama.Thermal and mechanical stabilities of Hi-Nicalon SiC fibers under annealing and creep in various oxygen partial pressures.Corros.Sci.50(2008)3132-3138.

[19]G.Kister,B.Harris. Tensile properties of heat-treated Nicalon and Hi-Nicalon fibers. Part A: Appl.Sci.Manuf. 33(2002)435-438

[20]Narottam P.Bansal.Mechanical properties of hi-Nicalon fibre-reinforced celsian composites after high-temperature exposures in air. J. Euro. Ceram. Soc. 29 (2009) 525-535.

[21]M.Takeda,A.Urano,J.Sakamoto,et al. Microstucture and Oxidation Behavior of Silicon Carbide Fibers Derived from Polycarbosilane. J. Am. Ceram. Soc. 83 (2000) 1171-1176. 